\title{
Além da Torre de Marfim: Inquérito conduzido pela prática e pesquisa pós-disciplinar
}

\author{
DOI Number \\ 10.24135/link 2021.v2i1.171.g318
}

Esta proposta considera as relações entre as práticas profissionais e pós-disciplinares na medida em que se relacionam com a pesquisa em design conduzida pela prática. Quando vistos através de lentes territoriais, os artefatos e sistemas que muitos designers desenvolvem em universidades podem ser considerados híbridos porque atraem para sua composição e contextos diversos campos disciplinares. Processualmente, o discurso parte de uma discussão sobre a maneira como as designações disciplinares, originadas na secularização das universidades alemãs no início do século XIX, tornaram-se o modelo de quanto conhecimento é processado atualmente na academia. Examina-se como essas demarcações de pensamento, que incluíam linguagens e literaturas não clássicas, ciências sociais e naturais e tecnologia, foram interrompidas nas décadas de 1970 e 1980, por disciplinas baseadas em identidades que cresceram dentro das universidades. Estas incluíram estudos de mulheres, lésbicas, gays e grupos étnicos. No entanto, de igual importância durante este período foi a chegada de disciplinas profissionais como design, jornalismo, enfermagem, gestão empresarial e hospitalidade. Significativamente, muitas dessas profissões trouxeram consigo valores e processos associados à pesquisa centrada no usuário. Moldados pela necessidade de responder de forma rápida e eficaz às oportunidades, os profissionais estavam acostumados a aproveitar e integrar o conhecimento livre de demarcações disciplinares ou profissionais. Por exemplo, se um estúdio de design exigisse a contribuição de um formulador de políticas do governo, um advogado de patentes e um engenheiro, este estúdio estaria acostumado a trabalhar de maneira flexível com diversos domínios do conhecimento na busca de um resultado eficaz. Além disso, essas profissões também empregaram diversas formas de investigação conduzida pela prática. Com base em altos níveis de experimentação, reflexão ativa e conhecimento profissional aplicado, essas abordagens desafiaram muitas pesquisas e convenções disciplinares dentro da academia. Embora a investigação conduzida pela prática, argumentada como uma forma de prática pós-disciplinaridade, seja um conceito relativamente novo (Ings, 2019), pode estar associado à observação de Wright, Embrick e Henke (2015, p. 271) de que "estudos pós-disciplinares emergem quando os acadêmicos se esquecem das disciplinas e as ideias podem ser identificadas com alguma em particular: eles se identificam com a aprendizagem e não com as disciplinas". Darbellay vai mais longe, ao enxergar a pós-disciplina como um repensar essencial do conceito de disciplina. $O$ autor sugere que quando os acadêmicos se posicionam fora da ideia de disciplinas, eles são capazes de "construir um novo espaço cognitivo, no qual não se trata mais apenas de abrir fronteiras disciplinares por meio de graus de interação / integração, mas de desafiar fundamentalmente o fato óbvio da disciplinaridade"(2016, p. 367). Esses autores argumentam que, a pós-disciplina propõe um profundo repensar não só do conhecimento, mas também das estruturas que o cercam e sustentam nas universidades. No campo do design, essas abordagens não são desconhecidas. Para ilustrar como a pesquisa conduzida pela prática em design pode operar como uma investigação pós-disciplinar, este trabalho emprega como estudo de caso o curtametragem Sparrow (2017). Ao fazer isso, descompactase a maneira como o conhecimento, de dentro e além dos campos disciplinares convencionalmente demarcados, foi reunido, interpretado e sintetizado criativamente. Aqui, sem restrições por demarcações disciplinares, um artefato projetado surgiu por meio de uma fusão de pesquisa que integrou história, medicina, desenvolvimento de software, políticas públicas, poesia, tipografia, ilustração e produção cinematográfica. 